\title{
Windpower contribution to sustainable development in Brazil
}

\author{
Moana Simas ${ }^{1, *}$, Sergio Pacca ${ }^{2}$ \\ ${ }^{1,2}$ University of São Paulo, São Paulo, Brazil \\ * Corresponding author. Tel: +55 11 9236-4152, E-mail: moana@usp.br
}

\begin{abstract}
Global electricity consumption rose exponentially over the last decades powered by fossil fueled thermal power plants. In comparison, Brazil relies on large hydroelectric plants to generate most of its electricity. Nevertheless, the share of thermal electricity generation in Brazil has increased because thermal power can balance the seasonality of the hydroelectric based system and is cost competitive. Regardless its great wind potential, the use of this technology in Brazil is still timid. The country had only 835 MW of installed windpower capacity until November 2010, or $0.75 \%$ of its total. An aggressive wind power deployment has been constrained by its cost until recently. However, windpower has potential to act as a complementary energy source to hydropower during dry seasons, and its development could displace thermal power plants. This paper aims to quantify potential greenhouse gas (GHG) emission reductions and jobs creation in three different scenarios of wind energy development up to 2019. In the baseline scenario, windpower will create over 93,000 jobs and reduce up to 96 million tones of $\mathrm{CO}_{2}$ by 2019. In comparison, a massive windpower deployment scenario, , foresees the reduction of up to 176 million tones of CO2 and the generation of more than 225,000 jobs, most of them in the manufacturing sector. Therefore, wind power is an important alternative for promoting sustainable development in Brazil because it reduces GHG emissions and creates green jobs.
\end{abstract}

Keywords: Wind power, Wind industry, Jobs, Sustainable development, Brazil

\section{Introduction}

Over the past years concerns on climate change left the scientific and environmental spheres and got strong social and political engagement. The establishment of carbon markets, coupled with international oil price volatility, stimulated a rapid development of renewable energy (RE) generation technologies [1]. RE generation systems are free of harmful emissions and their energy sources are ubiquitous. In comparison to other RE windpower stands out because despite its small share in the global electricity market, it was subject to a rapid growth in recent years [2].

A turning point for windpower development in Brazil was the renewable energy incentive program (Proinfa) of the Ministry of Mines and Energy, established in 2002. However, the high energy costs for wind projects compared to traditional and other renewable energy sources precluded a massive deployment of this energy technology. The realization of dedicated windpower auctions in 2009 and 2010 attracted more projects, making windpower more competitive with traditional fossil fueled power plants.

The Brazilian electricity mix encloses a significant share of hydropower. In 2009, this energy source was responsible for $85 \%$ of the total domestic electricity supply [3]. Windpower development in Brazil is unique because in the Northeast region, which contains approximately $50 \%$ of the Brazilian wind resource, besides high average wind speeds, its availability complements the hydrologic cycle [4]. Therefore, windpower can be used to match the power loss during the hydropower offseason displacing thermal power plants that are currently balancing the electricity supply [5].

Windpower could contribute in various ways for sustainable development (SD). Developing a clean RE source helps maintaining the low greenhouse gas (GHG) emission factor of the Brazilian grid. Moreover, the establishment of a domestic industry brings in innovation and the development of new indigenous technologies, in addition to new job positions [6], which 
become relevant as a response to economic crisis and sensible investments in RE must be evaluated according to this yardstick [7].

Nevertheless, the exploitation of the windpower potential depends on long term policies that facilitate the deployment of this RE source. Despite the recent success, the existing medium and long term official energy supply scenarios do not foresee a significant increase in the share of this energy source [8].

The current work aims to evaluate potential benefits and quantify the avoided emissions and the employment generation potential of windpower development in Brazil. Initially we carry on a brief review of the present state-of-the-art of windpower in Latin America (LA) and Brazil. Next, we assess the potential of this RE source in Brazil and we evaluate its contribution to SD and energy security in the country. Finally we compare different scenarios, which are based on official data and a massive windpower development vision.

\section{Windpower in Brazil}

Forecasts prepared by the Global Wind Energy Council (GWEC) consider LA as a promising windpower market due to its sizeable wind potential and increasing energy needs in the region [2]. In fact, since the beginning of the century, various countries in the region have implemented policies to support the development of RE, including windpower [9]. Over the last years, a timid growth was observed in the share of windpower in LA in comparison to Europe, North America, and Asia. In 2009, the installed capacity in LA doubled from 653 MW to 1,274 MW. However, until August 2010, only two countries were responsible for a significant share of windpower in LA. Brazil and Mexico were responsible for $44 \%$ and $29 \%$ of the total installed power in the region, respectively [10].

According to a recent GWEC assessment, Brazil has the largest windpower market potential in LA due to its large remaining wind resources, the ability to complement hydropower generation, and the possibility of hosting wind equipment manufacturing plants. Moreover, the country is considered as a future equipment supplier to the region [2].

Although the first wind turbine was installed in Brazil in 1992, in Fernando de Noronha Island [11] the share of windpower in the Brazilian matrix became noticeable only after 2006 with the first Proinfa results. A total of 54 wind projects totaling $1.4 \mathrm{GW}$ of installed capacity were supported by the Program [12], which was instrumental to the expansion of windpower in Brazil. Presently, Proinfa supported facilities are responsible for 95\% of the installed windpower capacity in Brazil, or 835 MW up to December 2010 and yet, its contribution corresponds to less than $1 \%$ of the total power capacity of the country.

Other milestone that has contributed to the installation of the wind manufacturing industry in the country was the $60 \%$ minimum requirement share of domestic equipments in wind projects [13].

Until 2009, the cost of the windpower based electricity was still a barrier to its expansion. The average electricity price of Proinfa projects in 2007 was in the range of \$119 to \$135 per MWh, depending on the individual capacity factor of each one [14]. Up to this point, windpower was considered unfeasible and not competitive despite the considerable potential that was revealed in the first national assessment at $143 \mathrm{GW}$ [15]. 
The turning point was due to a conjunction of good policies and global market conditions. In 2009, the first auction fully dedicated to windpower was commissioned. Possibly due to great availability of wind resources in areas with low population density, the variation of the exchange rate, and the economic crisis in 2008-2009, a significant supply of equipment was available and both domestic and international companies were led to invest in the Brazilian market. In August 2010, a second windpower auction took place, along with other RE sources in which, wind energy competed with small hydroelectric plants (SHP) and biomass cogeneration projects. For the first time wind energy prices $(\$ 73 / \mathrm{MWh})$ were below other RE prices [16]. Additional $6 \mathrm{GW}$ of windpower projects were enabled to participate in the auction [17], and certainly most of these will be hired in future.

Considering the projects assisted by Proinfa and by the latest auctions, more than $5 \mathrm{GW}$ of windpower will be added to the Brazilian grid by the end of 2013. It is more than the current $0.8 \mathrm{GW}$ but still far away from the total indigenous potential. Currently the country uses around $0.5 \%$ of its potential. If windpower electricity trade in dedicated auctions persists, the expansion trend continues and costs decrease over time. In the future windpower could occupy a significant share of electricity generation and complement the current hydro-thermal system.

In comparison to major future hydroelectric projects in the Brazilian Amazon, windpower resources are closer to energy load areas along the coast line (figure 1), and major transmission lines of the national grid [18]. Therefore, transmission costs and losses associated with windpower are smaller than the ones associated with large expected hydroelectric projects.
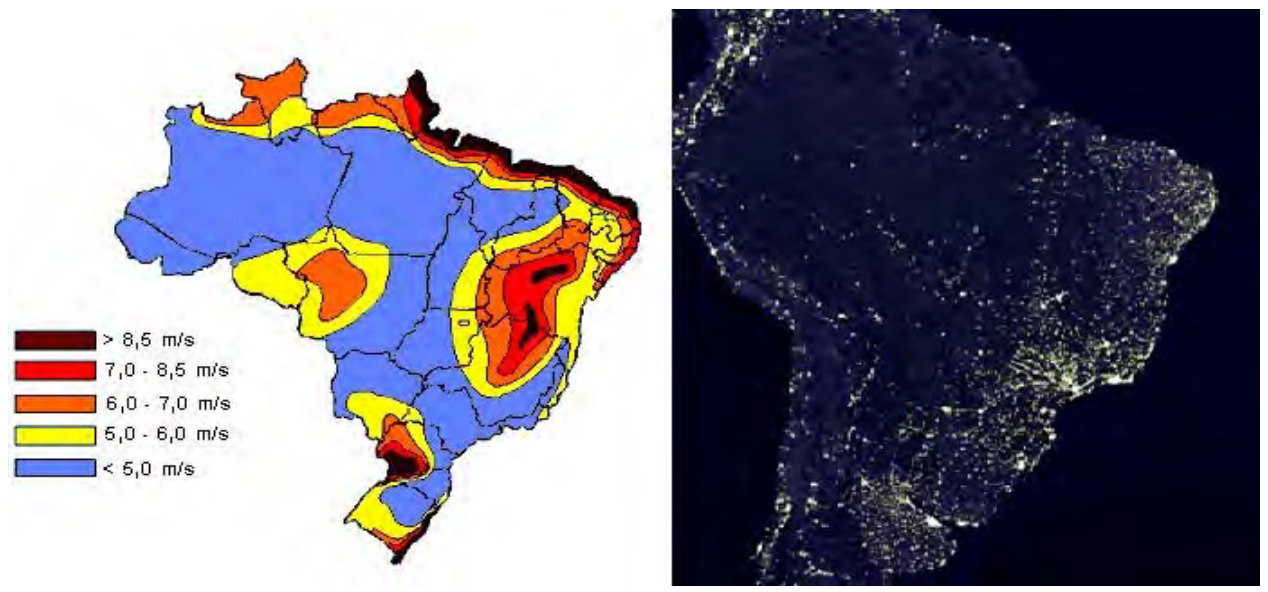

Fig. 1. Wind resources at a 50m height in Brazil [19] and its correlation to urban areas [20]

In summary, windpower that was considered unfeasible just one year ago is nowadays, not only competitive with other alternative energy sources, but also with traditional fossil fueled based electricity generation technologies. The turning point in Brazil was due to a conjunction of good policies and global market conditions. As a result, low impact windpower projects are a real supply option to meet power needs.

\subsection{Complementarity between wind energy and hydroelectricity}

RE face various difficulties such as high cost and resource intermittency. To increase the performance of RE, diversified complementary sources should be spatially and seasonally 
combined. Traditionally, thermal generation plants are used to support systems based on renewable sources. In recent years, alternative energy sources have been contemplated for this role [21]. This phenomenon can be observed in Brazil.

The share of renewable sources in the Brazilian energy matrix corresponded to $47 \%$ in 2009 , well above the world average. Moreover, hydropower comprises $85 \%$ of all electricity supply in the country, and additional 5\% comes from other RE sources [3]. The hydroelectric system encloses several large reservoirs, capable of multi-year regulation.

Nevertheless, due to environmental concerns, most of the future dams in Amazonia will be run-of-river hydroelectric plants, with lower dams [8], leading to further reliance on climatic conditions. Thus, because wind resource availability in the Northeast of Brazil complements hydrologic regimes, it could lead to optimal use of reservoirs [4]. Indeed, windpower might displace part of the fossil fuel based electricity generation, reducing pollution and maintaining the high share of RE in the Brazilian matrix.

\subsection{Economic benefits of windpower deployment}

Both climate and RE policies will change the way economies are currently structured. Climate change consequences may negatively affect the economy in most countries, especially the ones in which the contribution of vulnerable sectors, such as agriculture, plays an important role [22].

Investing in a low-carbon economy creates risks and opportunities. On the one hand, a few studies show that in the long run subsides in RE in Germany have led to high costs with few or no benefits to the economy [23,24,25]; on the other hand, most economy-wide studies show positive economic outcomes from investing in low-carbon technologies $[7,26,27]$.

According to Fankhauser et al (2008) [28], the most important benefit from climate and RE policies is innovation, which demands technical change adapted to a new market structure. The quest for new technologies and processes increases the demand for skilled labor, and countries that position themselves as leaders in low-carbon technologies might become key exporters. Over the past few years, Brazil has attracted various wind turbine manufacturers (e.g. Enercon, Impsa, GE), and due to the fast growing market, might become an exporter to other LA countries.

In periods of low economic growth, as the one seen in the financial crisis in 2008-2009, unemployment rates tend to grow, and so does the concern about job loss related to large amount of subsides invested in RE [7]. In fact, employment generation driven by $\mathrm{RE}$ promotion has been disputed, especially in the United States [28].

\subsubsection{Green Jobs}

According to the United Nations Environmental Programme (UNEP), green jobs are work in various activities that contribute to preserving or restoring environmental quality. Most studies reveal that RE is more labor-intensive than fossil fuel-based power generation $[27,29,30]$. Hence, the substitution of RE for fossil fuels leads to a positive net effect on employment. In Brazil, the creation of new jobs, due to windpower development, should be compared with the creation of jobs due to the development of concurrent alternatives such as hydro. 
Nevertheless, based on the available information about green jobs generation, global employment in the RE sector was above 2.3 million in 2006. Brazil is one of the most significant RE employer, with 500,000 jobs on the biomass sector. In contrast, globally, wind energy generated 300,000 jobs up to 2006, and it is expected that employment in this sector will reach 2.1 million in 2030 [22]. Most of these jobs are located in manufacturing, according to the level of domestic production of equipments [30].

\section{Methodology}

To quantify GHG emissions reductions and job generation in the wind sector, we used a baseline scenario up to 2019, developed by the Ministry of Mines and Energy. Based on that scenario, and the recent growth of the wind energy market in Brazil, we developed two alternative scenarios, one moderate and one optimistic. The scenarios have the following characteristics (Figure 2):

a) Scenario A, or Baseline Scenario, foresees an installed wind capacity of 6 GW by the end of 2019 [8];

b) Scenario B, or Moderate Scenario, estimates a raise of 50\% in the installed capacity up to the end of the period, resulting in $9 \mathrm{GW}$, based on expectations of the Brazilian Wind Energy Association (ABEEolica) of 10 GW in 2020 [31];

c) Scenario C, or Optimistic Scenario, predicts annual hiring of $1.5 \mathrm{GW}$ in exclusive windpower auctions, to be installed from 2013 onwards. By the end of the period, 14 GW of windpower capacity will be commissioned.

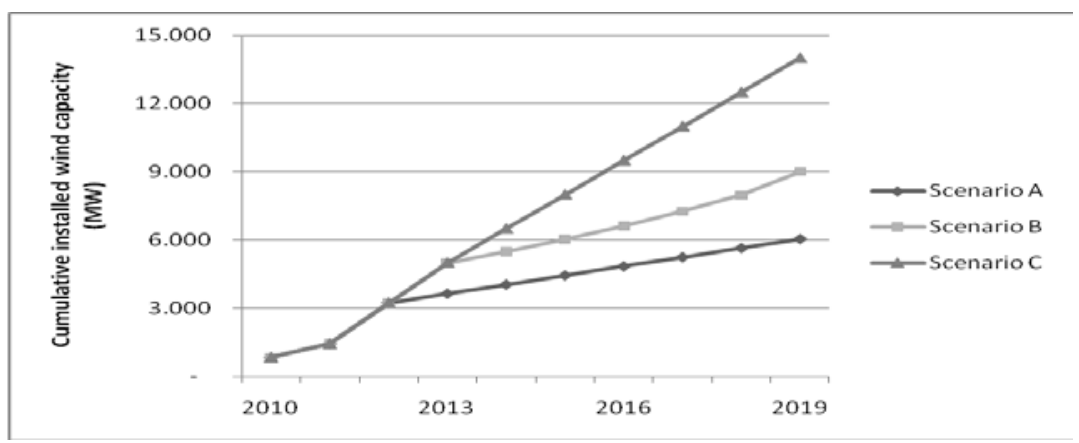

Fig. 2. Installed capacity in the years 2010-2019 in the three proposed scenarios

For estimating job creation, a multiplier provided by the Economical and Social Development Bank (BNDES) which estimates in 15 jobs/MW in manufacturing and construction and 0.4 jobs/MW in operation and maintenance of wind turbines [32]. These figures refer to total jobs, accounting direct and indirect employment over the supply chain.

For estimating potential GHG emission reduction, we considered that windpower displaces fossil fired power plants using natural gas and coal, the main thermal sources foreseen in the long-term national energy plan. Emission factors were taken from the International Energy Agency report, published in 2009 [33]. Emission reductions were estimated over the period between 2011 and 2020.

\section{Results}

Scenario A results in up to 96 million tons of $\mathrm{CO}_{2}$ reductions between 2011 and 2020 and yields 93,850 jobs, out of which, $83 \%$ are in the manufacturing and installation of wind farms.

Scenario B emission reductions are 34\% greater than scenario A, which mitigates up to 129 million tons of $\mathrm{CO}_{2}$ and generates over 143,000 jobs, $85 \%$ in manufacturing and installation. 
The most optimistic scenario foresees a reduction up to 176 million tons of $\mathrm{CO}_{2}-83 \%$ higher than in scenario A - and the employment of more than 225,000 people, $87 \%$ of them in manufacturing and installation.

According to the Brazilian Inventory of Anthropogenic Emissions and Removals of Greenhouse Gases, published in 2010 by the Ministry of Science and Technology, in 2005 the electricity generation, transmission and distribution emitted about 52 million tons of $\mathrm{CO}_{2}$ [34]. Scenario A suppressed $28 \%$ of the baseline emissions, while the scenario C reduces annual emissions by $65 \%$ in 2020 .

\section{Conclusions}

Wind energy is a source experiencing rapid growth worldwide. Following the trend, although timid, windpower market has rapidly developed in Brazil after Proinfa and mainly after the wind dedicated auctions of 2009 and 2010. Further expansion of the industry depends on continued support for RE in the country e.g. frequently auctions plus the inclusion of RE in medium and long term energy expansion plans.

This study shows the potential contributions that a significant expansion of wind capacity during this decade could bring to the country's sustainable development. The use of wind energy as a substitute for fossil-fuel power plants reduces up to 28\% GHG annual emissions in the electricity sector in the year 2020, based on the year 2005, in the scenario proposed by the government, while a scenario of intense deployment displaces up to $65 \%$ of these emissions.

The development of the wind industry brings several benefits such as innovation and technology transfer, and possibly the emergence of Brazil as a production center for wind equipment in Latin America. Nevertheless the more significant effect is the creation of 93,000 to 226,000 green jobs by 2019 .

\section{References}

[1] L. Bird, M. Bolinger, T. Gagliano, R. Wiser, M. Brown, B. Parsons, Policies and market factors driving wind power development in the United States, Energy Policy, 33, 2005, pp. 1397-1407.

[2] Global Wind Energy Council [GWEC], Global Wind 2009 Report, 2010.

[3] Empresa de Pesquisa Energética [EPE], Balanço Energético Nacional 2010 - Ano-base 2009 - Resultados preliminares, 2010. Available from <https://ben.epe.gov.br/>.

[4] R. M. Dutra, A. S. Szklo, Incentive policies for promoting Wind Power production in Brazil: Scenarios for the Alternative Energy Sources Incentive Program (PROINFA) under the New Brazilian electric power sector regulation, Renewable Energy, 33, 2008, pp. 65-76.

[5] A. Filgueiras, T. M. V. Silva, Wind energy in Brazil - present and future, Renewable and Sustainable Energy Reviews, 7, 2003, pp. 439-451.

[6] M. I. Blanco, G. Rodrigues, Direct employment in the Wind energy sector: An EU study, Energy Policy, 37, 2009, pp. 2847-2857.

[7] U. Lehr, J. Nitsch, M. Kratzat, C. Lutz, D. Edler, Renewable energy and employment in Germany, Energy Policy, 36, 2008, pp. 108-117. 
[8] Empresa de Pesquisa Energética [EPE], Plano Decenal de Energia 2019, 2010. Available

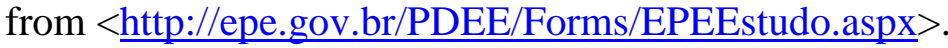

[9] S. Arango, E. R. Larsen, The environmental paradox in generation: How South America is gradually becoming more dependent on thermal generation, Renewable and Sustainable Energy Reviews, 14, 2010, pp. 2956-2965.

[10] Global Wind Energy Council [GWEC], 2010 apud Windpower Monthly, Special Report: Windpower in Latin America, August 2010, p. 9.

[11] M. S. M. Araújo, M. A. V. de Freitas, Acceptance of renewable energy innovation in Brazil - case study of wind energy, Renewable and Sustainable Energy Reviews, 12, 2008, pp. 584-591.

[12] Eletrobrás, Programa de Incentivos às Fontes Alternativas de Energia - PROINFA: Relação de Empreendimentos Contratados, 2010. Available from $<$ www.eletrobras.com $>$.

[13] Ministério de Minas e Energia [MME], Programa de Incentivo às Fontes Alternativas de Energia - PROINFA, 2010. Available from http://www.mme.gov.br/programas/proinfa.

[14] L. A. Lima, C. R. Bezerra Filho, Wind energy assessment and Wind farm simulation in Triunfo - Pernambuco, Brazil, Renewable Energy, 35, 2010, pp. 2705-2713.

[15] Centro de Pesquisas de Energia Elétrica [CEPEL], Atlas do Potencial Eólico Brasileiro,

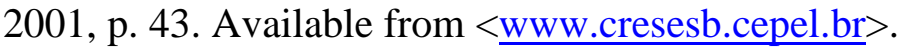

[16] Empresa de Pesquisa Energética [EPE], Leilões de Fontes Alternativas 2010, published on August 26, 2010. Available from <http://www.epe.gov.br/imprensa/PressReleases/20100826_1.pdf $>$.

[17] Empresa de Pesquisa Energética [EPE], EPE conclui habilitação técnica para Leilões de Fontes Alternativas, published on August 11, 2010. Available from <http://www.epe.gov.br/imprensa/PressReleases/20100811_1.pdf $>$.

[18] N. F. da Silva, L. P. Rosa, M. R. Araújo, The utilization of Wind energy in the Brazilian electric sector's expansion, Renewable and Sustainable Energy Reviews, 9, 2005, pp. 289-309.

[19] Centro Brasileiro de Energia Eólica [CBEE], Atlas Eólico do Brasil - Resultados preliminares, 1998.

[20] National Aeronautics and Space Administration [NASA], Astronomy picture of the day: Earth at night, published on November 27, 2000. Available from http://apod.nasa.gov/apod/ap001127.html.

[21] H. H. Chen, H. Kang, A. H. I. Lee, Strategic selection of suitable projects for hybrid solar-wind power generation systems, Renewable and Sustainable Energy Reviews, 14, 2010, pp. 413-421.

[22] UNEP/ILO/IOE/ITUC, Green Jobs: Towards Decent Work in a Sustainable, LowCarbon World, 2008

[23] R. Küster, I. R. Ellersdorfer, U. Fahl, A CGE-analysis of energy policies considering labor market imperfections and technology specifications, Fondazione Eni Enrico Mattei, Working Paper 73, 2007. 
[24] B. Hillebrand, H. G. Buttermann, J. M. Behringer, M. Bleuel, The expansion of renewable energies and employment effects in Germany, Energy Policy, 34, 2006, pp. 3484-3494.

[25] M. Fondel, N. Ritter, C. M. Schmidt, C. Vance, Economic impacts from the promotion of renewable energy technologies: The German experience, Energy Policy, 38, 2010, pp. 4048-4056.

[26] E. Jochem, R. Madlener, The forgotten benefits of climate change mitigation: Innovation, technological leapfrogging, employment and sustainable development, Working Paper OECD Working Party on Global and Structural Policy, 2003.

[27] M. Wei, S. Patadia, D. M. Kammen, Putting renewables and energy efficiency to work: How many jobs can the clean energy industry generate in the US? Energy Policy, 38, 2010, pp. 919-931.

[28] S. Fankhauser, F. Sehlleier, N. Stern, Climate change, innovation and jobs, Climate Policy, 8, 2008, pp. 421-429.

[39] J. Goldemberg, The case of renewable energies, Thematic Background Paper, International Conference for Renewable Energies, 2004.

[30] J. Rutovitz, A. Atherton, Energy sector jobs to 2030: A global analysis, Institute for

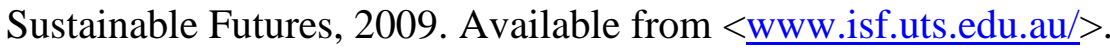

[31] Tony Danby, Interview with Brazilian wind industry vice president Lauro Fiuza, Windpower Monthly, published on August 13, 2010. Available from $<$ http://www.windpowermonthly.com/news/1022252>.

[32] Banco Nacional de Desenvolvimento Econômico e Social [BNDES], Um panorama da indústria de bens de capital relacionados à energia eólica, BNDES Setorial, Rio de Janeiro, 29, 2009, pp. 229-278.

[33] International Energy Agency [IEA], $\mathrm{CO}_{2}$ emissions from fuel combustion - Highlights, 2009, p. 14.

[34] Ministério de Ciência e Tecnologia [MCT], Inventário Brasileiro de Emissões Antrópicas por Fontes e Remoções por Sumidouros de Gases de Efeito Estufa não Controlados pelo Protocolo de Montreal - Parte 2, 2010. Available from $<$ http://www.mct.gov.br/upd_blob/0214/214061.pdf $>$. 